Gi respons på artikler gjennom artiklenes kommentarfelt på tidsskriftet.no.

Innleggene publiseres fortløpende på Tidsskriftets nettside og et utvalg

av innleggene publiseres også i papirutgaven i spalten «Brev til redaktøren».

Redaksjonen forbeholder seg retten til å foreta redaksjonelle endringer.

Forfattere av vitenskapelige artikler har tilsvarsrett, jf. Vancouver-gruppens regler.

\section{Re: Overdiagnostikk - norske allmennleger viser vei}

Roksund og medarbeidere fokuserer igjen meget treffsikkert på overdiagnostikk og sykeliggjøring i helsetjenesten (1). Jeg har selv flere ganger prøvd å få interesse blant indremedisinere om at sykdommen «arteriell hypertensjon» hviler på meget uvitenskapelig diagnostisk metodikk (mansjett-blodtrykk). Til tross for dette er det utført mange medikamentstudier på store pasientmaterialer. Konsekvensene koster samfunnet enorme resurser, særlig fordi vi må regne med at mange pasienter feilaktig får høre at de har «for høyt blodtrykk».

Det er helt elementært og selvfølgelig at trykkmåling med mansjett også registrerer stivhet og aldringsforandringer i arterien og fysiske forhold i muskulaturen. Dette i tillegg til psykiske forhold og hormoneffekter som også spiller inn. Vi får håpe at måling på begge overarmer og 24-timers måling selvsagt blir gjort. Men hvordan måle blodtrykket hos pasienter med permanent atrieflimmer? En meget anerkjent blodtrykksspesialist svarte meg at han ikke hadde noen problemer med trykkmåling hos disse. Det kaller jeg medisinsk tøv.

Uten å få tilstrekkelig respons fra kolleger har jeg etterlyst bruken av fundus-fotos både i diagnostikk og oppfølging. En absolutt objektiv (og praktisk gjennomførbar) målemetode får vi jo aldri, men det kunne blitt et godt hjelpemiddel.

Da jeg publiserte mine tanker om dette i Tidsskriftet (2) og senere i Dagens Medisin (3) fikk jeg flere e-poster fra utlandet, men null respons fra norske medier.

Hvorfor ikke heve hypertensjonsdiagnostikken opp på et vitenskapelig nivå?

\section{Carl Ditlef Jacobsen}

cd-j@online.no

Carl Ditlef Jacobsen (f. 1930) er pensjonert overlege og spesialist i indremedisin og i fordøyelsessykdommer.

Ingen oppgitte interessekonflikter.

\section{Litteratur}

1. Roksund G, Brodersen J, Johnson GE et al. Overdiagnostikk - norske allmennleger viser vei. Tidsskr Nor Legeforen 2016; 136: 1903-5.

2. Jacobsen CD. Har pasienten virkelig hypertensjon? Tidsskr Nor Legeforen 2012; 132: 1946

3. Jacobsen CD. Behov for kritisk blikk. Dagens Medisin 2.5.2016. https://www.dagensmedisin.no/artikler/2016/05/02/behov-for-et-kritisk-blikk/ (19.12.2016)

\section{Re: Les!}

Innlegget var rørande (1). Ovafor den døyande pasienten gjorde legen ein god jobb. Med all respekt for pasienten, dei pårørande og legen kjenner eg meg likevel forplikta til å nemna dette:

Denne pasienten har i sitt vaksne liv lidd av fortapingsangst. Årsaka var utan tvil førestellinga om at ein før det var for seint måtte velja mellom å overgje eg til Kristus, eller å gå fortapt. Det artikkelforfattaren ikkje finn verd å nemna er at den same religionsutøvinga som tidleg i livet hennar skapte denne angsten, i neste omgang kunne få æra for å ha fjerna han.

Denne sirkelen er eit døme på korleis nokre kristne forkynnarar og andre føresette skaffar seg makt over unge sjeler. I forsvarslaus barndom vert dei først innpoda skuldkjensle og fortapingsangst. Dernest vert dei med tilvising til same religiøse autoritet tilbydd probat boteråd - in casu tilgjeving - for å fjerna ein angst som den religiøse indoktrineringa sjølv har nedfelt $\mathrm{i}$ barnesinnet.
Det var bra at legen kunne vera til hjelp, og fortent og rørande at han fekk klem før han gjekk heim til tindrande barneauge. Att står likevel dette: Denne pasienten har som barn vore utsett for eit alvorleg overgrep. Dei som kunne trengja tilgjeving var ikkje pasienten, men dei vaksne som var skuldige i misferda.

\section{Vidar Lehmann}

v-lehma@online.no

Vidar Lehmann (f. 1938) er pensjonert lege.

Ingen oppgitte interessekonflikter.

Litteratur

1. Bråtveit A. Les! Tidsskr Nor Legeforen 2016; 136: 2022

\section{Re: Trombektomi bør gjøres tidlig}

I Tidsskriftet nr. 21/2016 under spalten «Fra andre tidsskrifter» presenteres en metaanalyse publisert i JAMA (1) som understreker betydningen av å komme raskt til endovaskulær behandling (trombektomi) ved akutt hjerneinfarkt. Overlege Eva Jacobsen ved nevroradiologisk seksjon på Rikshospitalet blir bedt om å kommentere artikkelen, og det er vanskelig å være uenig med henne $\mathrm{i}$ at resultatene viser at det er viktig med god logistikk både ved sykehus som primært mottar pasientene og sykehus der trombektomi utføres (2).

Det føles imidlertid betimelig å påpeke at denne typen studier også er et innlegg i debatten om hvor denne behandlingen skal tilbys og hvem som skal utføre prosedyren. Etter de oppsiktsvekkende gode resultatene fra flere randomiserte studier i 2015 hvor gunstig effekt av mekanisk trombefjerning i fremre kretsløp ble dokumentert for første gang, pågår det nå over hele verden en diskusjon om hvordan disse resultatene skal påvirke organiseringen av mottak av pasienter med akutt hjerneslag. Dette er en kompleks problemstilling hvor mange hensyn skal tas, blant annet fordi prosedyren, som Jacobsen sier, er teknisk krevende og medfører potensielt alvorlige komplikasjoner.

Her i Norge skal trombektomi diskuteres i Beslutningsforum for nye metoder. I rapporten fra Folkehelseinstituttet som skal danne grunnlaget for beslutningen som skal tas kan man lese: «Det synes nødvendig å etablere flere intervensjonssentra, eventuelt i samarbeid med andre intervensjonsradiologiske miljøer» (3). Mitt inntrykk fra blant annet nasjonalt møte om endovaskulær slagbehandling i Oslo oktober 2015 er at det finnes sterke meninger rundt dette spørsmålet hos toneangivende fagfolk. Jeg tror at en åpen faglig debatt om dette, for eksempel her i Tidsskriftet, ville komme pasientene til gode.

\section{Dag Ottar Sætre}

dagsat@so-hf.no

Dag Ottar Sætre (f. 1975) er overlege ved Avdeling for bildediagnostikk, Sykehuset $\emptyset$ stfold.

Ingen oppgitte interessekonflikter.

\section{Litteratur}

1. Saver JL, Goyal M, van der Lugt A et al; HERMES Collaborators. Time to treatment with endovascular thrombectomy and outcomes from ischemic stroke: a meta-analysis. JAMA 2016; 316: 1279-88.

2. Pettersen PM. Trombektomi bør giøres tidlig. Tidsskr Nor Legeforen 2016; 136 1794

3. Frønsdal KB, Skår Å, Stoinska-Schneider A et al. Mekanisk trombektomi ved akutt hjerneinfarkt. Mechanical thrombectomy for acute ischemic stroke. Rapport fra Folkehelseinstituttet 2016. Oslo: Folkehelseinstituttet, 2016. 